Маријана Папрић

Универзитет у Београду

Учитељски факултет

marijana.papric@uf.bg.ac.rs
УДК 81'25:811.161.1:371

https://doi.org/10.18485/slavistika.2019.23.2.11

Оригинални научни рад примљено 04.09.2019.

прихваћено за штампу 10.10.2019.

\title{
ПРЕВОЪЕЊЕ У НАСТАВИ РУСКОГ ЈЕЗИКА СТРУКЕ
}

У раду се разматра статус и улога превођења у професионално оријентисаној настави руског језика на друштвено-хуманистичким факултетима у Србији. Критички се сагледава његова заступљеност у студијским курикулумима и уџбеницима руског језика струке за поменути образовни профил. Указује се на позитивне стране, али и на извесне недостатке у концепцији и организацији наставе на нашим нефилолошким факултетима. Истиче се значај превођења као важне компоненте професионалне комуникативне компетенције потенцијалних стручњака у сфери хуманистике и нуде одређене сугестије и препоруке у циљу побољшања квалитета наставе превођења, као и наставе руског језика струке у целини.

Кључне речи: руски језик струке, настава превођења, студијски курикулум, уџбеник руског језика.

This paper examines the status and role of translating in the professionally oriented teaching of the Russian Language at Serbian faculties of humanistic science. Its representation in course curricula and textbooks of Russian for professional purposes for the mentioned educational profile is examined. The paper points out the positive aspects, but also some shortcomings in the concept and organization of teaching at non-philological faculties. The importance of translating is emphasized as an important component of professional communicative competence of future experts in the sphere of humanities. The paper also offers some suggestions and recommendations for the improvement of the quality of translation instruction and the teaching of the Russian Language for professional purposes.

Keywords: Russian Language for professional purposes, teaching translation, course curriculum, Russian Language textbooks.

У савременој професионално оријентисаној настави страних језика која има интердисциплинарни, интегративни каратер и комплекасан циљ - формирање лингвистичке, комуникативне, когнитивне, социокултурне, професионалне и међукултурне компетенције, умење превођења са страног језика на матерњи и обрнуто представља драгоцену вештину за стручњака било ког образовног профила. Оспособљавање студената за рад са стручном литературом, усвајање терминолошке лексике, као и праћење актуелних тенденција у сфери струке и науке, намећу потребу за овладавањем основама превођења како у филолошком, тако и у нефилолошком образовном профилу. Ако се уз то узме у обзир и чињеница да данас више од 95\% укупне преводилачке грађе чине пословни, научни и технички преводи (Корж 2015), онда потреба за обучавањем студената основним принципима и техникама превођења стручног текста све више добија на актуелности.

Модерни методи у настави руског језика, базирани на комбинованом свеснопрактичном и свесно-контрастивном моделу учења, примену превођења у на- 
стави не доводе у питање. Превођење као један од методских поступака и средстава у настави руског језика као страног нашао је своје теоријско утемељење и потврду у радовима еминентних руских и српских психолога, лингвиста и методичара: Б. В. Бељајева (Беляев 1965), В. Г. Костомарова, О. Д. Митрофанове (Костомаров, Митрофанова 1988), А. А. Леонтјева (Леонтьев 1988), И. А. Зимње (Зимняя 2001), В. Н. Комисарова (Комиссаров 2011), И. Ј. Поповић (Попович 2001, 2011), Л. В Московкина, А. Н. Шчукина (Московкин, Щукин 2012: 357362), Ј. А. Мисуно (Мисуно и др. 2013), М. Ј. Иљушкине (Илюшкина 2015), В. Н. Базиљева, В. Г. Красиљникове (Базылев, Красильникова 2017), Л. М. Алексејеве (Алексеева 2010, 2013), К. Кончаревић (2011), В. Раичевића (2007, 2016) и других.

Превођење је заступљено у свим етапама наставе и образовним профилима - од основног до високошколског, а у професионално оријентисаној настави руског језика оно има посебно место и улогу. Превођење се примењује у обради језичког и говорног материјала, нарочито при семантизацији апстрактне и терминолошке лексике, као и граматичких јединица које постоје само у руском језику (нпр. пасивних партиципских конструкција типа „книга, читаемая студентом, продукция выпускаемая заводом“). Превођење је неопходно при контрастирању таквих језичких појава као што је глаголска рекција (готовиться / к чему? спремати се / за шта?), повратност / неповратност глагола (учиться на курсах / похађати курс), међујезичка хомонимија (испьтывать страх / осећати страх) и лексичка спојивост (нпр. синтагма држати предавање на руски се преводи као читать лекцию; сликати икону као писать икону).

У раду се разматра досадашње искуство у настави превођења у контексту курса руског језика струке на друштвено-хуманистичким факултетима у Србији, критички се сагледава и оцењује његов статус у студијским курикулумима и уџбеницима руског језика за поменуте факултете, указује се на извесне тешкоће у раду и нуде опциона решења у циљу подизања квалитета наставе превођења у датом образовном профилу. Циљ рада је да покаже да превођење као специфичан вид говорне делатности са својим посебним лингвистичким и психолошким карактеристикама мора бити предмет посебног изучавања и овладавања, тј. имати адекватно место у наставним садржајима професионално оријентисане наставе руског језика.

\section{Превођење у студијским курикулумима за руски језик струке}

Да превођење представља важну компоненту наставних садржаја и истовремено један од циљева наставе руског језика струке показује анализа студијских курикулума и уџбеника руског језика за друштвено-хуманистичке факултете у Србији.

У већини нормативних докумената за руски језик које смо прегледали, као основни циљ наставе превођења наводи се оспособљавање студената за правилно реципирање и адекватно транспоновање текстова из области уже струке са руског језика на српски и обрнуто, као и развијање навика и техника служења речником и другом помоћном литературом (К РЈ1-РЈ2-РЈМ УФБГ; К РЈ2-РЈ3РЈМ УФЛ; К РЈ ПФБГ; К РЈ ПФН; К РЈ2 ФФБГ; К РЈ2-РЈМ ПБФ). С обзиром да 
је у настави руског језика струке акценат више на рецептивним компетенцијама, доминантно место у настави припада превођењу са руског на српски језик.

Иако су елементи превођења заступљени у готово свим студијским курикулумима из анализираног корпуса, најдетаљнији опис наставе превођења даје се у курикулумима за руски језик на Филозофском и Православном богословском факултету у Београду.

Тако се као један од циљева наставе руског језика на Филозофском факултету наводи превођење стручне литаратуре, а садржаји наставе обухватају основне принципе превођења, потенцијално и контекстуално значење речи, важност екстралингвистичких фактора и комуникативне ситуације, рад са речником и компоненте речничког чланка. Посебна пажња поклања се граматичким проблемима превођења, као и основним изворима грешака у превођењу. Стога је у садржаје наставе укључено превођење партиципских и пасивних конструкција у научном тексту, превођење реченица са значењем потпуног или делимичног одрицања, критеријуми вредности превода - верност оригиналу и језичким нормама матерњег језика, одлике усменог и писменог превођења (К РЈ2 ФФБГ).

Као финални циљ наставе превођења на Православном богословском факултету у Београду наводи се оспособљеност студената за превођење религиолошког и теолошког текста уже струке (К РЈМ ПБФ). Као један од парцијалних циљева наставе наводи се развијање способности опсервирања и анализирања појава и елемената руског језичког система у циљу правилног декодирања и проналажења адекватних преводних еквивалената у српском језику (К РЈ1 ПБФ). Практичном наставом обухваћени су нивои еквивалентности у превођењу, врсте текстова и типови превођења. Студенти се упознају са различитим преводилачким поступцима као што су парафраза, адаптација, превођење нееквивалентне лексике, пермутације, додавање, одузимање, изостављање и друге технике. Осим тога студенти се оспособљавају за коришћење помоћне литературе при превођењу и упознају се са основним одликама писменог и усменог консекутивног превођења (К РЈ2 ПБФ).

Извесне корекције унели бисмо у курикулуме за руски језик на појединим учитељским, педагошким и филозофским факултетима у којима је настава превођења сведена на оспособљавање студената за коришћење различитих типова речника или је у потпуности изостала из наставних садржаја. Примедбе би се односиле на Учитељски факултет у Ужицу (К РЈ1-РЈ2 УФУ), Педагошки факултет у Сомбору (К РЈ1-РЈ2 ПФС) и филозофске факултете у Нишу (К РЈ1-РЈ2 $Ф Ф Н)$ и Новом Саду (К РЈ Б1.1- Б1.2- Б2.1- Б2.2 ФФНС). Наведене курикулуме требало би допунити елементима превођења, односно експлицирати садржаје које би обухватила настава ове специфичне говорне делатности.

Предложене корекције односиле би се и на курикулуме за руски језик на Учитељском факултету у Врању (К РЈ1-РЈ2 УФВ) и Факултету педагошких наука у Јагодини (К РЈС ФПНЈ) на којима се елементи превођења фрагментарно помињу тек на дипломским (мастер) академским студијама. Наш предлог је да се елементи превођења укључе у курикулуме већ на основним академским студијама, те да се бар оквирно наведу преводилачки поступци, технике или 
проблеми који ће бити предмет изучавања и усвајања у оквиру курса руског језика струке на поменутим факултетима (детаљније в: Папрић 2016: 387-390).

\section{Превођење у уџбеницима руског језика струке}

Анализа актуелних уџбеника руског језика струке за друштвено-хуманистичке факултете потврђује да превођење, уз наставу читања, писања и говорења, има важно место у наставним садржајима професионално оријентисане наставе руског језика. Од будућих стручњака очекује се не само оспособљеност за читање, разумевање, прераду и продуковање садржаја из области уже струке у писменој и усменој форми, већ и вештина адекватног транспоновања датих садржаја са руског на српски језик и обрнуто.

Да се вештином превођења мора овладавати, тј. да се овој вештини студенти морају посебно обучавати, сведочи велики прој преводилачких задатака и вежбања које смо пронашли у уџбеницима руског језика струке из анализираног корпуса.

Превођење се одвија у два правца - са руског на српски и обрнуто, при чему су аутори водили рачуна о дозирању новог лексичког материјала, као и градирању вежбања по тежини. Тако се у уџбеницима могу наћи вежбе различитог типа и степена сложености, почев од једноставних - превођења речи на бази прочитаног текста, синтагми, реченица, једноставнијих дијалога и краћих везаних текстова, до дужих, језичко-стилски и синтаксички сложенијих текстова за превод на руски и српски језик.

Посебна пажња посвећује се вежбањима за развој језичког наслућивања на бази контекста, сличности са речима интернационалног карактера или на основу позитивног трансфера из матерњег - српског језика (РЯРК; РЈ ВОТ; ВОИ; РЈУФ С). Занимљиво је да у новијим уџбеницима руског језика струке нема семантизације нових речи, већ се студентима сугерише да на одабраним примерима или у контексту самостално протумаче значења тражених речи и израза (ВОИ; РЈ ВОТ). Евидентно је да се за овакав поступак у презентацији лексичког материјала аутори нису определили случајно, те да је циљ био да се код студената постепено проширује рецептивни и потенцијални лексички фонд, подстичу технике самосталног читања и тумачења стручног текста, уз максималну мобилизацију свих језичких знања, ослонац на контекст и вештину језичког наслућивања.

Вежбе превођења базирају се углавном на текстовима научног стила, мада су у извесној мери у уџбеницима присутни и елементи административно-пословног, информативног, разговорног и књижевноуметничког превођења.

Наставу превођења у области научног стила најбоље репрезентује уџбеник Руски језик у теологији: обликовање теолошког текста - техника превођења (в. Изворе). У поменутом уџбенику детаљно су описани различити преводилачки поступци и технике превођења на одабраним материјалима из области теологије и понуђен низ репрезентативних вежбања за примену описаних поступака и техника (парафраза, адаптација, превођење нееквивалентне лексике, пермутације, додавање, одузимање, изостављање, превођење дефиниција, превођење термина, унутарлексичка системност у превођењу, транслитерација и транскрипција). 
Као репрезент наставног превођења у области свих других функционалних стилова - административно-пословног, информативно-публицистичког и књижевноуметничког може послужити књига Руски језик у комуникаиији и мисији Цркве: функиионални стилови, ресурси, жанрови (в. Изворе). У поменутој књизи пронашли смо драгоцене примере превођења административно-пословне документације (обавештења везана за школовање, молбе, радне биографије (CV), рекламе, фрагменте из различитих нормативних докумената и слично), текстове информативно-публицистичког стила (вести, аналитичке коментаре и интервјуе) и примере књижевноуметничког превођења (духовне поуке, фрагменте из молитвених дневника, богословске стослове, језгрене сакралне жанрове - молитве, кондаке, тропаре, херетизме, акатисте и посланице). Управо по широком спектру вежбања за превођење садржаја различитих функционалних стилова, укључујући и књижевноуметнички, поменути уџбеник се разликује од свих осталих уџбеника из анализираног корпуса.

Општи утисак је да су аутори домаћих уџбеника руског језика струке за друштвено-хуманистичке факултете адекватно оценили значај и улогу наставе превођења, те су у уџбеничке садржаје укључили репрезентативни број преводилачких вежби различитог типа и степена сложености. Доминантно место припада писменом преводу, док је усмени консекутивни превод заступљен једино у уџбенику Руски језик у теологији: обликовање теолошког текста - техника превођења. Мишљења смо да би шире укључивање вежби усменог превођења у знатној мери обогатило наставне садржаје, утицало на развој умења усменог изражавања и подигло квалитет наставе руског језика струке у целини.

Такође се залажемо за укључивање у наставу превођења елемената других функционалних стилова, нпр. информативно-публицистичког (актуелних вести из области струке, интервјуа са признатим стручњацима) и административнопословног (информација везаних за студирање, формулара за упис на факултет, молбе, радне биографије) чији би задатак био да будуће стручњаке припреме за сналажење у реалним животним ситуацијама као што су аплицирање за наставак студија, програме мобилности, специјализацију или послове у иностранству. Кратки сегменти из одабраних књижевноуметничких остварења написаних савременим руским књижњевним језиком могу бити укључени у уџбеник у виду факултативних прилога за студенте који желе да додатно читају и преводе и на тај начин обогаћују и унапређују своја знања о руској култури, обичајима и традицији (детаљније в: Папрић 2016: 391-436).

\section{Проблеми наставе превођења на нефилолошким факултетима}

За разлику од филолошких факултета на којима превођење представља посебан предмет изучавања, те се студентима нуде специјални курсеви превођења на основним и мастер студијама, на нефилолошким факултетима превођење није издвојено у посебан аспект наставе, већ се усваја комплексно, тј. паралелно са другим језичким вештинама - читањем, писањем, слушањем и говорењем. Због тога исходи наставе превођења у великој мери зависе од саме концепције курса језика струке, тј. од вештине наставника да у релативно кратак временски оквир (најчешће само три семестра на основним студијама) (Папрић 2018) на адеква- 
тан начин укључе елементе стручног превођења, односно имплементирају их у студијски курикулум и уџбеник страног језика струке.

За успешно развијање умења превођења стручне литературе, студенти нефилолошких факултета, поред лингвистичке компетенције (знања о функционисању страног језичког система, познавање основних одлика научног стила, укључујући и знања о систему матерњег језика), морају поседовати још и предметну компетенцију (научна и стручна знања неопходна за разумевање и правилно транспоновање на језик превода уже стручних текстова) и стратегијску компетенцију (познавање различитих поступака, техника и стратегија превођења) (Гавриленко 2015; Корж 2015; Đorđević 2017: 59-64). Неуједначно и неретко нестабилно предзнање руског језика, мали фонд часова другог страног језика у претходном школовању, као и позиционираност курса језика струке у прва три семестра студија када предметна компетенција студената још увек није у довољној мери формирана, отежава не само процес наставе, већ и рад наставника који у почетним фазама курса мора бити репрезент не само језичких, већ и професионалних, тј. стручних знања, што не спада у домен његових професионалних компетенција (Корж 2015). Решење овог проблема видимо у сарадњи наставника страног језика струке са наставницима других стручних предмета (Мирић, Ђоровић 2015), интензивирању курса језика струке, тј. повећању фонда часова и продужавању трајања курса на минимум четири семестра, уз могућност факултативног похађања курса на вишим годинама студија (укључујући мастер и докторске студије).

\section{Лингвистички проблеми превођења}

Лингвистички проблеми у настави превођења везани су углавном за тешкоће у идентификацији и правилном транспоновању на језик превода терминолошке лексике, међујезичких хомонима, полисемичних речи, као и сложенијих глаголских облика и синтаксичких конструкција својствених језику струке и науке (Волгина 2013; Карпенко 2010; Ордян 2018; Папрић 2015; 2017; Đorđević 2017: 79-83).

Узмимо, на пример, термин педагог који студенти најчешће преводе дословно, не узимајући у обзир специфичну разлику у употреби овог термина у руском и српском језику. Тако у примеру «Куклы шьются педагогами или детьми самостоятельно» (Лутке шију васпитачи или деца самостално) преузетом из текста «Вальдорфский детский сад. Что это такое?» (ВОИ: 219), наслов текста и сам контекст сугеришу да се у датом случају недвосмислено ради о васпитачу, а не о педагогу.

Анализирајући и поредећи значења термина педагог на основу речничких одредница у руском и српском језику, В. Белокапић-Шкунца указује да на семантичком плану нема разлике. Међутим, потенцијални проблеми у транспоновању на српски језик могу се објаснити неподударањем у фреквентости појединих значења датог термина у два језика. Док у српском језику термин педагог најчешће означава стручњака за педагогију, у руском језику најфреквентнија значења су учитељ, наставник, професор или просветни радник (БелокапићШкунца 2011). 
Тешкоће у превођењу ствара и нееквивалентна лексика, као и културолошки маркирани термини који немају своје еквиваленте у језику превода, те се при њиховом транспоновању прибегава коментарима или описним дефиницијама које се обично дају у подножној напомени уз транслитерован или калкиран израз (нпр.: Радоница - Радоњица, „у руској православној традицији дан помена упокојених у уторак после Светле недеље“; Яблочный Cnac - Jaбучни Cnac, „руска народна традиција освећивања јабука на празник Преображења 19. августа“; единоверие - јединоверије / једноверје, „условно обједињење старовераца са Православном Црквом“") (Кончаревић 2011: 119-120).

Посебну групу потенцијално проблематичних лексема за превод чине:

1. међујезички хомоними: лекиия - предавање; лекција - урок (РЈ УФВ: 47); наставлять - учити, поучавати; настављати - продолжать (РЈ УФВ: 90); бан$\kappa a$ - тегла, лименка; банк - банка (РЈ ФФН I: 41); 2. пароними: проявление - появление - явление (РЈП: 29); мировой-всемирный-мирный-миролюбивый (РЈ ПОЛ: 94); крестный (nуть, ход) - крёстный (отеи, сын) (РЈ КМЦ: 64); обсуждать / обсудить и осуждать / осудить (РЯРК: 132); 3. полисемичне речи, нпр. образ: - 1. создать что-н. по своему образу и подобию; светлый образ матери; поэт мыслит образами; артист вошёл в образ; образ жизни, образ мыслей; каким образом? таким образом; образ: - 2. то же, что икона: старинный образ в окладе (РЈ УФС: 78-79).

На синтаксичком плану највише проблема уочено је при превођењу конструкција са глаголским прилозима и партиципима, пасивних конструкција у којима је субјекат изражен инструменталом, у превођењу са пермутацијама реченичних делова (нпр. превођење парцијалне негације) или самих реченица у оквиру сложене реченице, као и превођењу дефиниција, на пример:

Психолог в детском саду - это прежде всего знающий и глубоко понимающий ребёнка человек, разбирающийся [...] в общих закономерностях и в возрастных особенностях психического развития детей [...].(Психолог у дечјем вртићу је пре свега човек који познаје и дубоко разуме дете, који се разуме [...] у опште законитости и узрасне карактеристике психичког развоја детета [...]) (ВОИ: 179);

Эти меры направлены на предупреждение получения детьми с нарушенной моторикой травм и ушибов. (Ове мере усмерене су на то да се спрече трауме и повреде деце са нарушеном моториком) (РЈ УФБ: 91);

Затем от имени Сербской Православной Церкви Святейшим Патриархом Павлом был дан прием в честь Святейшего Патриарха Московского и всея Руси Алексия II и возглавляемой им делегации Русской Православной Церкви. (Затим је у име Српске Православне Цркве Његова Светост Патријарх Павле приредио пријем у част Свјатјејшего Патријарха Московског и целе Русије Алексија II и делегације Руске Православне Цркве коју је он предводио) (РJ КМЦ: 181);

Так как нет человека, который не грешил бы, каждому необходимо преодолевать склонности к греховным поступкам. (Свако треба да савлађује склоност према греховним поступцима, јер нема човека који не греши) (РJT: 113); 
Специфика детского развития состоит в том, что она подчиняется не действию биологических законов, как у животных, а действию общественно-исторических законов. (Специфичност дечјег развоја је у томе што оно не подлеже деловању биолошких закона као код животиња, него деловању друштвеноисторијских закона (РЈ УФС: 146).

\section{Закључак}

Резултати анализе показују да превођење као специфичан вид говорне делатности подразумева не само одређена лингвистичка, већ и екстралингвистичка, тј. предметна знања - познавање ширег научног контекста, упућеност у уже-стручну област која је предмет стручног превођења, владање терминосистемом дате области, развијене навике служења терминолошким речницима, енциклопедијским приручницима и другом помоћном литературом, али и ширу општу културу. Због тога је за успешно бављење стручним превођењем неопходно перманентно усавршавање лингвистичке, комуникативне и културолошке компетенције, константно учење и напредовање на пољу струке и науке (Кончаревић 2011).

За овладавање овом специфичном и сложеном рецептивно-продуктивном говорном делатношћу коју према наводима И. А. Зимње чини укупност добро развијеног смисаоног реципирања, осмишљавања и репродуктивног мишљења (Зимняя 2001: 128), студенти се морају специјално оспособљавати и обучавати. Наставна пракса показује да владање основним видовима говорне делатности не подразумева и владање превођењем, стога је у наставне садржаје курса страног - руског језика струке неопходно укључити елементе превођења који би уз наставу читања, писања, слушања и говорења чинили основу комуникативне, међујезичке и међукултурне компетенције будућих стручњака у сфери професионалне комуникације.

Наставници језика струке јасно су уочили значај ове специфичне говорне делатности, те су укључили превођење у студијске курикулуме и уџбенике руског језика струке. Међутим, резултати истраживања показали су да у важећим нормативним документима постоји извесна неуједначеност у погледу заступљености елемената превођења, те су предложене одређене корекције и допуне у циљу оптимизације наставе, односно адекватног укључивања превођења у наставне садржаје језика струке.

Анализа уџбеника руског језика за друштвено-хуманистичке факултете показала је да и поред широког спектра преводилачких вежбања у уџбеницима доминира писмени превод, док је усмени превод готово сасвим изостао из наставе. Превођење се углавном врши на примерима и одломцима из текстова научносг стила, док су примери других функционалних стилова веома слабо заступљени.

Наш предлог је да се у уџбенике руског језика струке поред писменог уведу и вежбе усменог консекутивног превођења, као и елементи превођења на одабраним примерима из административно-пословне, информативно-публицистичке, разговорне и књижевно-уметничке сфере. Наставни садржаји који би обухватили елементе других функционалних стилова и који би поред писменог подстицали и усмени превод, дали би настави превођења нови квалитет и пружили додатни подстицај за учење руског језика у домену професионалне комуникације. 


\section{Цитирана литература}

Алексеева, Лариса М. Специфика научного перевода (антропоцентрический аспект). Пермь: Пермский гос. нац. исслед. ун-т, 2013.

Алексеева, Лариса М. «Методика обучения письменному переводу специального текста». Вестник Пермского университета 2 (8), 2010: 77-84<http://www.rfp.psu. ru/archive/2.2010/alexeeva.pdf> 25.3.2019.

Базылев, Владимир Н., Варвара Г. Красильникова (под ред. В. Н. Базылева). Дидактика перевода. Хрестоматия и учебные задания: учебное пособие. Москва: ФЛИНТА, 2017.

Беляев, Борис В. Очерки по психологиии обучения иностранным языкам. Москва: Просвещение, 1965.

Белокапић-Шкунца, Вера. „Педагошка терминологија“ [У]: Игњачевић, А. и др. (ур.) Језик струке: изазови и перспективе: зборник радова. Београд: Друштво за стране језике и књижевности Србије, 2011: 770-775

Волгина, Мария Ю. «Перевод терминов как ключевых единиц специального текста». Перспективы Науки и Образования 6, 2013: 170-175<https://cyberleninka.ru/ article/n/perevod-terminov-kak-klyuchevyh-edinits-spetsialnogo-teksta $>$ 22.3.2019.

Гавриленко, Наталия Н. «Попытка систематизации переводческих компетенций». Вестник ПНИПУ. Проблемы языкознания и педагогики 2 (12), 2015: 70-77<https:// cyberleninka.ru/article/n/popytka-sistematizatsii-perevodcheskih-kompetentsiy> 15.3.2019.

Зимняя, Ирина А. Лингвопсихология речевой деятельности. Москва: Московский психолого-социальный институт, Воронеж: НПО «МОДЭК», 2001.

Илюшкина, Мария Ю. Теория перевода: основные понятия и проблемы (учебное пособие). Екатеринбург: Изд-во Урал. ун-та, 2015.

Карпенко, Н. М. «Перевод текстов по специальности как важная составляющая профессионально-ориентированного обучения. Вопросы и проблемы». Записки Горного института Т. 187, 2010: 267-269 <https://cyberleninka.ru/article/n/ perevod-tekstov-po-spetsialnosti-kak-vazhnaya-sostavlyayuschaya-professionalnoorientirovannogo-obucheniya-voprosy-i-problemy> 21.4.2019.

Корж, Татьяна Н. «Обучение студентов неязыковых специальностей переводу в сфере профессиональной коммуникации» [В]: Н. И. Алмазова и др. (ред.) Вопросы методики преподавания в ВУЗЕ 4 (18). Санкт-Петербург: Издательство политехнического университета, 2015: 243-251

Комиссаров, Вилен Н. Современное переводоведение. Москва: Р. Валент, 2011.

Кончаревић, Ксенија. Руски језик у теологији: обликовање теолошког текста - техника превођења. Београд: Православни богословски факултет, 2011.

Костомаров, Виталий Г., Ольга Д. Митрофанова. Методическое руководство для преподавателей русского языка иностранцам. Москва: Русский язык, 1988.

Леонтьев, Алексей А. Методика: заочный курс повышения квалификации филологов русистов. Москва: Русский язык, 1988.

Мирић, Милица, Данијела Ђоровић. „Настава страних језика на универзитету: сарадња наставника језика струке и наставника стручних предмета“. Настава и васпитање 64 (3), 2015: 507-520 
Ордян, Лилит А. «Типичные проблемы и особенности перевода научного текста». Молодой учёный 48 (234), 2018: 423-426 <https://moluch.ru/archive/234/54398/> 25.04.2019.

Мисуно, Екатерина А. и др. Письменный перевод специальных текстов: учебное пособие. Москва: ФЛИНТА, 2013.

Московкин, Леонид В., Анатолий Н. Щукин. Хрестоматия по методике преподавания русского языка как иностранного. Москва: Русский язык. Курсы, 2012.

Папрић, Маријана. „Проблеми наставе превођења у раду са студентима Учитељског факултета“" [У]: V. Cakeljić, A. Vujović, M. Stevanović (ur.) Zbornik radova. III Međunarodna konferencija Strani jezik struke: prošlost, sadašnjost, budućnost. Beograd: Fakultet organizacionih nauka, 2015: 383-390

Папрић, Маријана. Систем наставе руског језика као језика струке на хуманистичким студијама у српској говорној и социокултурној средини. Докторска дисертација (рукопис). Филолошки факултет, Београд, 2016.

Папрић, Маријана. „О лингвистичким аспектима наставе руског језика струке“. Славистика XXI/1-2, 2017: 229-237

Папрић, Маријана. „Савремена настава руског језика струке: проблеми и перспективе“. Иновације у настави XXXI/1, 2018: 43-57

Попович, Ирина Ю. Роль и место учебного перевода в практическом курсе русского языка как иностранного. Автореф. дис. ... канд. пед. Наук. Москва: ГИРЯ им. А. С. Пушкина, $2001<$ http://nauka-pedagogika.com/viewer/15609/d\#?page=1> 15.4.2019.

Попович, Ирина Ю. «Место перевода с родного языка в процессе усвоения русского языка как иностранного». Теория и практика общественного развития 2 , 2011: 368-370<http://cyberleninka.ru/article/n/mesto-perevoda-s-rodnogo-yazyka-vprotsesse-usvoeniya-russkogo-yazyka-kak-inostrannogo $>$ 15.4.2019.

Раичевић, Вучина. Општа методика наставе словенских језика у инословенској средини. Београд: Завод за уџбенике, 2007.

Раичевић, Вучина. „Превођење у настави страних језика - функција, место и задаци“. Славистика XX, 2016: 388-393

Đorđević, Jasmina P. Neknjiževni tekst u savremenom prevodilaštvu. Niš: Filozofski fakultet, 2017.

\section{Извори}

\section{Студијски курикулуми}

К РЈ1-РЈ2 УФБГ - Курикулуми за Руски језик 1 и 2 на основним академским студијама Учитељског факултета у Београду (2014)

К РЈМ УФБГ - Курикулум за Руски језик на дипломским (мастер) академским студијама Учитељског факултета у Београду (2014)

К РЈ1-РЈ2 УФУ - Курикулуми за Руски језик 1 и 2 на основним академским студијама Учитељског факултета у Ужицу (2014)

К РЈ2-РЈ3 УФЛ - Курикулуми за Руски језик 2 и 3 на основним академским студијама Учитељског факултета у Лепосавићу (2013)

К РЈМ УФЛ - Курикулум за Руски језик на дипломским (мастер) академским 
студијама Учитељског факултета у Лепосавићу (2013)

К РЈ1-РЈ2 УФВ - Курикулуми за Руски језик 1 и 2 на основним академским студијама Учитељског факултета у Врању (2014)

К РЈ1-РЈ2 ПФС - Курикулуми за Руски језик 1 и 2 на основним академским студијама Педагошког факултета у Сомбору (2014)

К РЈС ФПНЈ - Курикулум за Руски језик струке на основним академским студијама Факултета педагошких наука у Јагодини (2014)

К РЈ2 ФФБГ - Курикулуми за Руски језик 2 на основним академским студијама Филозофског факултета у Београду (2014)

К РЈ Б1.1- Б1.2- Б2.1- Б2.2 ФФНС - Курикулуми за Руски језик за језичке нивое од Б1.1 до Б2.2 на основним академским студијама Филозофског факултета у Новом Саду (2013)

К РЈ1-РЈ2 ФФН - Курикулуми за Руски језик 1 и 2 на основним академским студијама Филозофског факултета у Нишу (2014)

К РЈ ПФБГ - Курикулум за Руски језик на основним академским студијама Правног факултета у Београду (2013)

К РЈ ПФН - Курикулум за Руски језик на основним академским студијама Правног факултета у Нишу (2014)

К РЈ2 ПБФ - Курикулум за Руски језик 2 на основним академским студијама Православног богословског факултета у Београду (2014)

К РЈМ ПБФ - Курикулум за Руски језик на дипломским (мастер) академским студијама Православног богословског факултета у Београду (2014)

\section{Уйбеницุи}

PJ ВОТ - Белокапић-Шкунца, Вера. Руски језик: васпитно-образовна тематика. Београд: Универзитет „Браћа Карић“, 2009.

РЈ УФВ - Богдановић, Стојче. Руски језик за студенте Учитељског факултета. Врање: Учитељски факултет, 1998.

РЈ ФФН I - Величковић, Драгољуб. Руски језик I за студенте Филозофског факултета. Ниш: Филозофски факултет, 1993.

РЯРК - Дамљановић, Дара. Русский язык, русская культура: для студентов гуманитарного профиля. Београд: Завод за уџбенике, 2009.

РЈ УФС - Јермоленко, Наталија. Руски језик за студенте Учитељског факултета. Сомбор: Учитељски факултет, Центар за издавачку делатност, 2004.

PJT - Кончаревић, Ксенија. Руски језик у теологији: обликовање теолошког текста, техника превођења. Београд: Православни богословски факултет, Институт за теолошка истраживања, 2011.

РЈ КМЦ - Кончаревић, Ксенија. Руски језик у комуникацији и мисији Цркве: функционални стилови, ресурси, жанрови. Београд: Православни богословски факултет, Институт за теолошка истраживања, 2014.

РЈ ПОЛ - Маројевић, Радмило. Руски језик за политикологе. Београд: Научна књига, 1976.

РЈП - Милинковић, Љубо. Руски језик за правнике. Београд: Савремена администрација, 2000. 
ВОИ - Папрић, Маријана, Вера Белокапић Шкунца. Воспитываем, обучаем, играем: уџбеник руског језика за студенте Учитељског факултета. Београд: Учитељски факултет, 2015.

РЈ УФБ - Pecović, Miroslava. Ruski jezik: udžbenik za studente učiteljskih fakulteta. Beograd: Učiteljski fakultet, 1997.

\title{
Марианна Паприч
}

\section{МЕСТО ПЕРЕВОДА В ОБУЧЕНИИ РУССКОМУ ЯЗЫКУ ПРОФЕССИОНАЛЬНОГО ОБЩЕНИЯ}

\begin{abstract}
Резюме
В предлагаемой работе рассматриваются место и роль перевода в обучении русскому языку профессионального общения на гуманитарных факультетах в Сербии. Проводится критический анализ с точки зрения его представленности в актуальных учебных программах и учебниках по русскому языку на данных факультетах, отмечаются положительные стороны, а также некоторые недостатки, в концепции и организации обучения переводу студентовнефилологов. Подчеркивается роль перевода как важной составляющей профессиональной коммуникативной компетенции будущих специалистов в области гуманитарных наук, а также предлагаются определенные рекомендации с целью повышения качества обучения переводу и русскому языку профессионального общения в целом.

Ключевые слова: язык профессионального общения, русский язык, обучение переводу, учебная программа, учебник русского языка.
\end{abstract}

